\title{
PENGELOLAAN ARSIP LEMBAGA PEMERINTAHAN: STUDI PADA DINAS KEARSIPAN DAN PERPUSTAKAAN KABUPATEN CILACAP
}

\author{
Albertoes Pramoekti Narendra \\ Fakultas Teknologi Informasi \\ Universitas Kristen Satya Wacana Salatiga. \\ Email: albertoes1pramoekti@gmail.com.
}

\begin{abstract}
ABTRAK
Setiap organisasi baik pemerintah maupun swasta di dalam proses aktivitasnya akan menghasilkan rekaman informasi kegiatan yang disebut sebagai arsip. Didalam kehidupan organisasi dikenal adanya arsip dinamis dan arsip statis. Pengelolaan jenis arsip ini mengalami perbedaan mengingat masing-masing memiliki nilai guna yang berbeda. Penelitian ini ingin mengetahui secara lebih mendalam mengenai pengelolaan arsip di lembaga pemerintahan, khususnya pada Dinas Kearsipan dan Perpustakaan Kabupaten Cilacap yang juga mendapatkan pengakuan atas prestasinya. Penelitian ini menggunakan metode kualitatif deskriptif dengan metode wawancara bersama arsiparis. Hasil dari penelitian ini diketahui bahwa pengelolaan arsip di lembaga pemerintah diatur dengan berbagai pedoman dan peraturan pemerintahan. Pelayanan kearsipan juga dikembangkan berbasis teknologi informasi. Adapun pengelolaan arsip statis khususnya berupa akuisisi arsip dilaksanakan pada instansi yang bubar, di merger dan atau dilikuidasi. Akuisisi dilakukan pada arsip yang bernilai statis dan atau memiliki retensi diatas 10 tahun.
\end{abstract}

Kata Kunci: Arsip, Arsip Statis, Lembaga Pemerintahan, Pengelolaan Arsip.

\section{ABSTRACT}

Every organization, both government and private, in the process of its activities will produce a record of activity information which is called an archive. In organizational life, there are dynamic archives and static archives. The management of this type of archive is different considering that each has a different use value. This study wants to know more deeply about archive management in government institutions, especially at the Dinas Kearsipan dan Perpustakaan Kabupaten Cilacap which also received recognition for its achievements. This study uses a descriptive qualitative method with interviews with archivists. The results of this study note that archive management in government institutions is regulated by various government guidelines and regulations. Archival services are also developed based on information technology. The management of static archives, especially in the form of archive acquisition, is carried out in agencies that are disbanded, merged and/or liquidated. The acquisition is carried out on archives that have static value and or have retention of more than 10 years.

Keywords: Archives, Static Archives, Government Institutions, Records Management. 


\section{PENDAHULUAN}

Di dalam kegiatan organisasi baik pemerintah maupun swasta akan menghasilkan rekaman informasi yang disebut sebagai arsip. Arsip sebagai hasil dari proses aktivitas organisasi harus dikelola dengan baik. Kata arsip bersumber dari kata arheion (bahasa Yunani) dan archivum (bahasa Latin) yang berarti kantor pemerintah dan kertas yang disimpan di kantor tersebut, yang semula diterapkan pada record atau rekaman pemerintah (Sulistyo-Basuki, 1996).

Menurut Hadiwardoyo dan Yuniarti (2007:1.3) secara etimologis pengertian arsip dapat dibedakan menjadi dua, yaitu pengertian Eropa Continental dan pengertian Inggris Raya atau Anglo-Saxon. Di lingkungan Eropa, menyebutkan istilah arsip (archief) untuk semua jenis naskah yang dibuat atau diterima oleh suatu instansi dalam pelaksanaan fungsi kedinasan. Sedangkan dalam pengertian Inggris arsip adalah semua naskah yang dibuat atau diterima dalam pelaksanaan fungsi kedinasan suatu instansi dikenal dengan nama "record" (rekod).

Salah satu kepentingan mengelola arsip dinamis aktif, inaktif dan statis dalam rangka menjamin keselamatan arsip sebagai pertanggungjawaban nasional dalam kehidupan masyarakat, bangsa dan negara. Oleh karena itu maka di setiap lembaga kearsipan, pengelolaan arsip disesuaikan dengan wilayah kewenangan yang selalu terus menerus menambah ruang lingkup dan kazanah arsip statisnya dari sumber arsip atau pemilik arsip. Penambahan khazanah arsip dengan cara proses penyerahan maupun ganti rugi oleh lembaga kearsipan kepada pihak yang memberikan arsip statisnya.

Menurut Barthos (2009: 101) istilah arsip meliputi 3 pengertian: 1) kumpulan naskah atau dokumen yang disimpan; 2) gedung (ruang) penyimpanan kumpulan naskah atau dokumen 3) organisasi atau lembaga yang mengelola dan menyimpan kumpulan naskah atau dokumen. Menurut Sulistyo-Basuki (2003:13) Arsip dinamis (record) artinya informasi terekam, termasuk data dalam sistem komputer, yang dibuat atau diterima oleh badan korporasi atau perorangan dalam transaksi kegiatan atau melakukan tindakan sebagai bukti aktivitas tersebut. Definisi tersebut merujuk kepada mengapa arsip dinamis diciptakan dan alasan mengapa arsip dinamis disimpan. Arsip dinamis yang disimpan menunjang kegiatan sehingga disimpan sebagai bukti aktivitas tersebut.

Penelitian tentang pengelolaan arsip telah dilakukan oleh beberapa peneliti. Penelitian pertama berjudul "Pengelolaan Arsip Statis pada Badan Perpustakaan, Arsip dan Dokumentasi Provinsi Sumatera Utara" dalam Jurnal JIPI vol. 3, No. 1 tahun 2018 yang dilakukan oleh Nur'aini dari Pascasarjana Ilmu Perpustakaan dan Informasi Alumni Universitas Islam Negeri Sunan Kalijaga Yogyakarta. Hasil penelitian mengungkap bahwa pengelolaan arsip statis pada dan Perpustakaan, Arsip dan Dokumentasi Provinsi Sumatera Barat meliputi pengumpulan arsip statis, membuat Daftar Pertelaan Arsip Sementara (DPAS), Pelabelan Arsip, Penyimpanan, Penempatan Arsip, Pemeliharaan, Sistem temu balik Arsip Statis, dan penyelamatan.

Penelitian kedua berjudul "Pengelolaan arsip dinamis aktif di Kantor cabang Perum Pegadaian Marapalam Padang" dalam Jurnal Ilmu Informasi Perpustakaan dan Kearsipan Vol. 1, No. 1, September 2012, yang dilakukan oleh Rico Rahmadeni dan 
Syahyuman. Hasil penelitian agar penyimpanan arsip dinamis aktif pada Kantor Cabang Perum Pegadaian Marapalam Padang dapat terlaksana dengan baik, maka hal yang perlu diperhatikan antara lain; (1) untuk menghindari kesalahan dalam penyimpanan arsip dinamis aktif, sebaiknya sistem penyimpanan arsip dinamis aktif dilengkapi dengan sistem penyimpanan secara kronologis. Sistem penyimpanan secara kronologis dapat mempermudah petugas dalam melakukan temu kembali arsip; (2) memiliki petugas yang berpendidikan dan berlatar belakang kearsipan, serta petugas harus lebih teliti dalam melakukan penyimpanan dan mengelompokkan arsip dinamis aktif.

Dari kedua penelitian tersebut, peneliti berpendapat bahwa terdapat unsur yang membedakan dengan penelitian yang sudah dilakukan beberapa tahun sebelumnya. Unsur penting dalam penelitian ini adalah bahwa lembaga yang diteliti merupakan lembaga yang mendapatkan pengakuan terhadap prestasi pengelolaan kearsipan baik di tingkat provinsi maupun tingkat nasional.

Provinsi Jawa Tengah merupakan salah satu provinsi yang memiliki perhatian terhadap pengelolaan arsip yang semakin baik dan dapat dimanfaatkan oleh masyarakat. Salah satu upaya tersebut adalah menyelenggarakan lomba kearsipan tingkat provinsi. Mengacu pada publikasi dalam situs Dinas Kearsipan dan Perpustakaan Provinsi Jawa Tengah terpilih ada beberapa kabupaten yang menjadi pemenang dalam lomba bidang Kearsipan tingkat Provinsi Jawa Tengah yaitu Kabupaten Wonosobo, Kabupaten Magelang dan Kabupaten Cilacap.

Secara khusus penelitian ini memfokuskan pada Dina Kearsipan dan Perpustakaan Kabupaten Cilacap yang merupakan salah satu lembaga pemerintahan yang memiliki prestasi dalam pengelolaan arsip di tingkat provinsi Jawa Tengah pada tahun 2019 dan meraih prestasi terbaik nasional pada tahun 2017. Berdasarkan pada pengakuan yang telah diperoleh itu, menjadi salah satu daya tarik untuk mengetahui lebih mendalam bagaimana pengelolaan arsip di lembaga pemerintahan khususnya dalam penelitian ini pada Dinas Kearsipan dan Perpustakaan Kabupaten Cilacap yang karena kinerjanya dalam pengelolaan arsip memperoleh pengakuan prestasi dari pemerintah provinsi dan juga dari pemerintah pusat melalui Arsip Nasional Republik Indonesia.

\section{KAJIAN LITERATUR \\ Pengelolaan Arsip Dinamis}

Pengelolaan arsip dinamis meliputi penciptaan arsip, penggunaan arsip pemeliharaan serta penyusutan arsip (Endang Nurjati, 2016). Dalam Undang-Undang Nomor 43 Tahun 2009 dijelaskan bahwa pengelolaan arsip dinamis adalah proses pengendalian arsip dinamis secara efisien, efektif, dan sistematis meliputi penciptaan, penggunaan dan pemeliharaan, serta penyusutan arsip. Jadi, dapat ditarik suatu kesimpulan bahwa pengelolaan arsip dinamis adalah suatu rangkaian proses untuk mengendalikan terhadap arsip dinamis secara efektif, efisien dan sistematis yang terdiri dari kegiatan penciptaan, penggunaan dan pemeliharaan serta proses penyusutan arsip. Secara lebih lanjut pengelolaan arsip dinamis melalui proses pelaksanaan untuk menjamin ketersedian arsip sehingga menjamin dalam terselenggaranya kegiatan lembaga sebagai bahan akuntanbilitas kinerja dan alat bukti yang sah dengan berlandaskan pada sistem yang berlaku pada lembaga tersebut. 


\section{Arsip Statis}

Arsip statis mengandung berbagai macam pengertian. Sebagai bahan pengetahuan dan sebagai bahan perbandingan, dibawah ini pengertian tentang arsip statis adalah:

1. Dalam Undang-undang Nomor 43 Tahun 2009, yang dimaksud dengan arsip statis adalah arsip yang dihasilkan oleh pencipta arsip karena memiliki nilai guna kesejarahan, telah habis retensinya, dan berketerangan dipermanenkan yang telah diverifikasi baik secara langsung maupun tidak langsung oleh Arsip Nasional Republik Indonesia dan / atau lembaga kearsipan.

2. Menurut Wursanto (199: 237) "arsip statis sering disebut archive atau permanent record, yaitu arsip - arsip yang tidak secara langsung dipergunakan dalam penyelenggaraan administrasi negara."

3. Menurut Sedarmayanti ( 2003: 9) "arsip statis adalah arsip yang tidak dipergunakan secara langsung untuk perencanaan, penyelenggaraan kehidupan kebangsaan pada umumnya maupun untuk penyelenggaraan sehari-hari administrasi negara.

- Wursanto (1991: 238-239) memberikan waktu penyimpanan untuk masing-masing golongan arsip dalam tabel sebagai berikut:

Tabel 1: Waktu Penyimpanan Golongan Arsip

\begin{tabular}{|l|l|l|}
\hline No & Golongan Arsip & Waktu Penyimpanan \\
\hline 1 & Arsip Vital & Permanen \\
\hline 2 & Arsip Penting & $3-7$ tahun \\
\hline 3 & Arsip Biasa & $2-3$ tahun \\
\hline 4 & Arsip Tidak Penting & 1 tahun \\
\hline
\end{tabular}

Sumber: Wursanto (1991: 238-239)

Dapat dijelaskan bahwa dari empat jenis arsip tersebut yang masuk dalam kategori arsip permanen adalah Arsip Vital. Arsip vital merupakan arsip yang memiliki nilai historis, nilai keilmiahan, dan memiliki kegunaan yang sifatnya langgeng. Berkenaan dengan hal itu maka arsip tersebut harus tetap tersedia dalam bentu aslinya dan tidak tergantikan. Arsip vital disimpan secara permanen.

Pendapat lain dikemukakan oleh Terry yang dikutip oleh Wursanto (1991: 239) dijelaskan bahwa arsip biasa cukup disimpan selama 4-5 minggu saja. Sedangkan arsip penting disimpan selama 5-6 tahun. Kegiatan untuk menetapkan jangka waktu menyimpan arsip merupakan salah satu aktivitasa dalam kegiatan penyusutan arsip. Adapun arsip yang masih memiliki nilai guna tetapi tidak secara langsung digunakan dalam aktivitas perencanaan, penyelenggaraan administrasi negara kemudian disebut sebagai arsip statis dan diserahkan kepada Arsip Nasional RI, arsip yang diserahkan ke Arsip Nasional memiliki taraf simpan permanen dan memiliki nilai guna abadi.

\section{Hubungan Arsip Dinamis dengan Arsip Statis}

Hubungan kerja arsip dinamis dengan manajemen arsip statis menurut Ricks digambarkan sebagai berikut: 


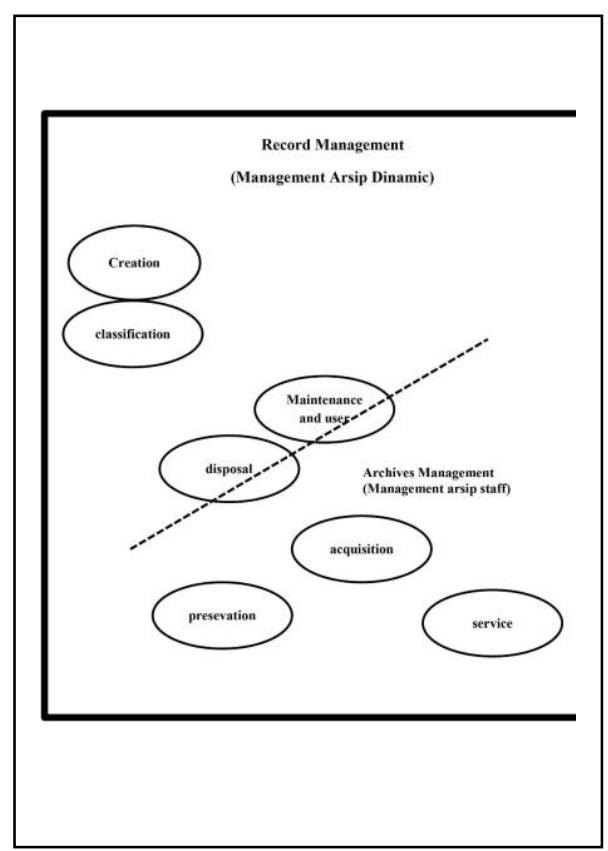

\section{Gambar 1 Record Management (Manajemen Arsip Dinamis)}

Sumber: Ricks (1992: 101-102)

Menurut Ricks (1992: 101-102), garis putus-putus menunjukkan kurang tegasnya pemisahan atau pembagian pertanggungjawaban seorang records manager dan seorang archivist (antara seorang arsiparis yang menangani kearsipan dinamis dan statis). Dalam kondisi inilah dibutuhkan adanya koordinasi yang tidak terputus sehingga terhindar dari adanya overlapping atau tumpang tindih pekerjaan antara bidang arsip dinamis dan arsip statis.

Pertimbangan lain juga mengenai masa simpan arsip dimana untuk arsip dinamis inaktif jika sudah habis masa simpannya untuk tahap selanjutnya untuk dinilai atau disusutkan. Dari hasil penilaian diketahui apakah apakah dilakukan pemusnahan atau pelestarian. Jika sebuah arsip ditetapkan untuk dilestarikan, maka arsip akan menjadi arsip statis. Di dalam proses menilai dan menetapkan untuk tahap penyusutan diperlukan kerjasama di kedua pihak, sehingga memperoleh hasil yang terbaik dan maksimal. Setelah disepakati menjadi arsip statis kemudian proses akuisisi dapat dilanjutkan.

\section{METODE PENELITIAN}

Penelitian ini menggunakan metode penelitian deskriptif kualitatif. Djam'an Satori (2011: 23) mengungkapkan bahwa penelitian kualitatifdilakukan karena peneliti ingin mengeksplor fenomena-fenomena yang tidak dapat dikuantifikasikan yang bersifat deskriptif seperti proses suatu langkah kerja, formula suatu resep, pengertian-pengertian tentang suatu konsep yang beragam, karakteristik suatu barang dan jasa, gambar- 
gambar, gaya-gaya, tata cara suatu budaya, model fisik suatu artifak dan lain sebagainya.

Menurut Nana Syaodih Sukmadinata (2011: 73), penelitian deskriptifkualitatif ditujukan untuk mendeskripsikan dan menggambarkan fenomena-fenomena yang ada, baik bersifat alamiah maupun rekayasamanusia, yang lebih memperhatikan mengenai karakteristik, kualitas, keterkaitan antar kegiatan. Selain itu, Penelitian deskriptif tidak memberikan perlakuan, manipulasi atau pengubahan pada variabel-variabel yang diteliti, melainkan menggambarkan suatu kondisi yang apa adanya. Satu-satunya perlakuan yang diberikan hanyalah penelitian itu sendiri, yang dilakukan melalui observasi, wawancara, dan dokumentasi.

Penelitian kualitatif memungkinkan peneliti untuk menyesuaikan diri dan tetap terbuka terhadap berbagai situasi dilapangan yang bisa berubah-ubah. dengan pendekatan studi kasus, yaitu peneliti menjelaskan secara mendalam tentang pengelolaan arsip (Bogdan dan Taylor dalam Moleong, 2013: 3). Sedangkan pendekatan studi kasus menurut Sulistyo-Basuki (2006: 113) yaitu, penelitian yang dikaji secara mendalam mengenai suatu peristiwa yang terjadi pada kondisi tertentu yang kemungkinan dapat di ungkapkan.

Di dalam penelitian ini, sumber data yang digunakan yaitu sumber data primer dan sumber data sekunder. Menurut Sulistyo-Basuki (2006: 102) "Sumber data primer adalah sumber yang merupakan bagian dari atau langsung berhubungan dengan peristiwa sejarah". Data primer yang digunakan dalam penelitian ini adalah hasil wawancara dan observasi langsung ke tempat penelitian baik data dalam bentuk tulisan atau gambar. Data sekunder dalam penelitian ini adalah informasi dari buku-buku, dan jurnal perpustakaan dan informasi maupun artikel.

Subjek dalam penelitian ini adalah orang-orang yang bekerja di Dinas Kearsipan dan Perpustakaan Kabupaten Cilacap yaitu kelompok jabatan fungsional arsiparis. Sedangkan yang termasuk objek dalam penelitian ini adalah aktivitas pengelolaan arsip Dinas Kearsipan dan Perpustakaan Kabupaten Cilacap.

Metode pengumpulan data yang dilakukan peneliti adalah wawancara, observasi dan dokumentasi. Informan dalam penelitian ini berjumlah satu. Informan ditentukan menggunakan teknik purposive sampling. Teknik purposive sampling merupakan adalah "teknik penentuan sampel dengan pertimbangan tertentu" (Sugiyono, 2012: 126).

Teknik penganalisisan yang digunakan dalam penelitian ini adalah teknik analisis data menurut Miles dan Huberman dalam Sugiyono (2012: 246) dilakukan melalui tiga tahap kegiatan, yaitu : (1) Reduksi data, (2) Penyajian data, (3) Penarikan kesimpulan.

\section{HASIL DAN PEMBAHASAN}

Pada bagian ini akan peneliti jelaskan mengenai hasil penelitian yang telah dilakukan berdasarkan observasi, wawancara, dan studi dokumentasi. Penelitian dengan judul "Pengelolaan Arsip Lembaga Pemerintahan, Studi pada Dinas Kearsipan dan Perpustakaan Kabupaten Cilacap". Desain penelitian yang digunakan pada penelitian ini adalah desain kualitatif dengan pendekatan studi kasus. Subjek dalam penelitian ini merupakan informan yang memberikan data wawancara.

Berdasarkan kriteria pemilihan informan dalam penelitian ini adalah Arsiparis Dinas Kearsipan dan Perpustakaan Kabupaten Cilacap. 


\section{Pengelolaan arsip Dinas Kearsipan dan Perpustakaan Kabupaten Cilacap dalam meraih predikat sebagai juara.}

Dinas Kearsipan dan Perpustakaan Kabupaten Cilacap mampu menjadi salah satu lembaga yang mendapat pengakuan juara lomba kearsipan tingkat provinsi Jawa Tengah dan tingkat nasional.

Hal pokok yang menjadi kelebihan Dinas Kearsipan dan Perpustakaan Kabupaten Cilacap sehingga menjadi juara bidang Kearsipan dikemukakan sebagai berikut:

Dinas Kearsipan dan Perpustakaan Kabupaten Cilacap sudah melakukan pengelolaan arsip baik dinamis maupun statis sesuai dengan ketentuan kearsipan. Upaya tersebut antara lain diupayakan dengan beberapa cara sebagai berikut:

1. Penataan: melaksanakan penataan arsip hasil akuisisi dari beberapa instansi sudah bubar atau di merger.

2. Penyusutan: melaksanakan pemusnahan arsip hasil penilaian yang beretensi musnah yang sudah ditetapkan oleh Bupati melalui kegiatan pembuburan/pulping sampai hancur sehingga tidak tersisa fisik maupun isi informasinya.

3. Pembinaan: melaksanakan pembinaan kearsipan bagi perangkat desa, petugas pengelola arsip SKPD, organisasi politik, BUMD, sekolah.

4. Layanan Arsip: melakukan layanan arsip baik secara langsung maupun secara virtual.

Dinas Kearsipan dan Perpustakaan Kabupaten Cilacap memiliki sarana penyimpanan arsip inaktif berupa depot arsip.

1. Ada 4 ruang depot arsip yang digunakan untuk menyimpan arsip statis maupun inaktif yang beretensi lebih dari 10 (sepuluh) tahun. Masing-masing depot arsip dilengkapi dengan sarana pengatur suhu antara lain AC, Smoke Detector, pengatur suhu ruangan, troly untuk mengangkut arsip.

2. Setiap satu tahun sekali dilaksanakan fumigasi, yaitu upaya pemeliharaan dan perawatan arsip dari gangguan hewan perusak arsip seperti ngengat dan kutu buku, kecoak, semut dll, dengan menggunakan bahan kimia yang bekerja sama dengan rekanan / pihak ketiga.

Dinas Kearsipan dan Perpustakaan Kabupaten Cilacap memiliki ruang Wisata Arsip.

- Dalam rangka memberikan layanan kearsipan baik kepada masyarakat umum maupun kedinasan, Dinas Kearsipan dan Perpustakaan Kabupaten Cilacap menyiapkan ruang audio visual untuk menampilkan film sejarah maupun film kearsipan dan film 4 dimensi untuk anak-anak. Ruang wisata arsip yang berisikan foto-foto sejarah nasional maupun sejarah lokal Kabupaten Cilacap.

Dinas Kearsipan dan Perpustakaan Kabupaten Cilacap memiliki peraturan perundangan tentang kearsipan sebagai berikut:

1. Peraturan Daerah Kab.Cilacap No. 4 Tahun 2018 tentang Penyelenggaraan Kearsipan. 
2. Peraturan Bupati Cilacap Nomor 84 Tahun 2019 tentang Pedoman Penyusutan Arsip di Lingkungan Pemerintah Kabupaten Cilacap.

3. Peraturan Bupati Cilacap Nomor 85 Tahun 2019 tentang Pedoman Akses dan Layanan Arsip Dinamis dan Statis di Lingkungan Pemerintah Kabupaten Cilacap.

4. Peraturan Bupati Cilacap Nomor 86 Tahun 2019 tentang Pedoman Pola Klasifikasi Kearsipan di Lingkungan Pemkab Cilacap.

5. Peraturan Bupati Cilacap Nomor 87 Tahun 2019 tentang Pedoman Pengelolaan Arsip Vital di Lingkungan Pemkab Cilacap.

6. Peraturan Bupati Cilacap Nomor 88 Tahun 2019 tentang Tata Cara Akuisisi

7. Arsip Statis di Lingkungan Pemkab Cilacap.

8. Peraturan Bupati Cilacap Nomor 224 Tahun 2019 tentang Pedoman Pengelolaan Arsip inaktif di Lingkungan Pemkab Cilacap.

9. Peraturan Bupati Cilacap Nomor 225 Tahun 2019 tentang Jadwal Retensi Arsip Substantif urusan Perindustrian, Ketenagakerjaan, Ketransmigrasian, Perpustakaan, Pendidkan dan Pelatihan, Kearsipan dan Kepegawaian.

Dinas Kearsipan dan Perpustakaan Kabupaten Cilacap memiliki sumberdaya manusia kearsipan yang kompeten. Saat ini memiliki sumber daya manusia kearsipan sejumlah 6 orang yang terdiri dari arsiparis kategori ketrampilan 4 orang dan arsiparis kategori keahlian 2 orang.

Unsur penilaian tersebut yang mampu dipenuhi sehingga Dinas Kearsipan dan Perpustakaan Kabupaten Cilacap menjadi juara bidang Pengelolaan Kearsipan. Selain unsur pada nomor 1 yang dinilai, pada saat penilaian lomba, Dinas Kearsipan dan Perpustakaan Kabupaten Cilacap menyajikan SKPD dan Desa Binaan yang memiliki kelebihan dalam pengelolaan arsip, selain itu juga menyajikan dan mengantarkan tim penilai lomba ke tempat bersejarah di Kabupaten Cilacap yang berhasil dikembangkan dalam rangka mendukung kelestarian sejarah di Kabupaten Cilacap.

\section{Pengelolaan Arsip}

Siklus Hidup Rekod Aktif

Didalam pelaksanaan kegiatan tata kearsipan maka Dinas Kearsipan dan Perpustakaan Kabupaten Cilacap juga memiliki siklus hidup dokumen/record aktif. Siklus hidup dokumen/record aktif di kantor Dinas Kearsipan dan Perpustakaan Kabupaten Cilacap:

1. Penciptaan dan penerimaan

Pada tahap ini, banyak arsip tercipta dari internal dinas maupun terima dari instansi/SKPD/Lembaga lain. Diterima, dicatat dan dikendalikan, untuk saat ini sudah menggunakan aplikasi ASOKA. Model klasifikasi dokumen kearsipan, substantif dan fasilitatif.

Sistem pengklasifikasian dokumen /arsip baik substantif maupun fasilitatif menggunakan alfa numeric. System klasifikasi arsip ini ditetapkan dalam Peraturan Bupati Cilacap.

2. Pendistribusian: Setelah melalui tahap penciptaan dan penerimaan, arsip didistribusikan ke bidang sesuia disposisi pimpinan. 
3. Penggunaan: Pada tahap ini ditindaklanjuti dan digunakan serta diselesaikan sesuai dengan kebutuhan.

4. Penyimpanan dan temu kembali: Setelah selesai tahap penggunaan, arsip di simpan pada filling cabinet, dengan system alfanumerik, menggunakan sarana map gantung.

5. Pemusnahan: Tahap akhir dari siklus hidup arsip adalah pemusnahan. Pemusnahan dilaksanakan untuk arsip yang beretensi musnah setelah dilakukan penilaian sesuai dengan Jadwal Retensi Arsip. Selanjutnya arsip yang beretensi musnah, setelah di beri persetujuan oleh Panitia Penilai dan Pemusnahan Arsip dan ditetapkan oleh Bupati dan Kepala ANRI, dilakukan pemusnahan secara total.

Proses pengelolaan arsip inaktif

Arsip inaktif diolah di ruang pengolahan arsip. Adapun tahapan pengolahan arsip inaktif adalah sebagai berikut:

1. Pemilahan: merupakan kegiatan memilah arsip untuk menemukan mana yang arsip dan mana yang non arsip.

2. Pemberkasan: Setelah tahap pemilahan dilanjutkan pemberkasan, yaitu memberkaskan arsip hasil pemilahan sesuai klasifikasi masalahnya.

3. Pendeskripsian: tahap pendiskripsian merupakan tahap menguraikan isi berkas hasil pemberkasan dan dituangkan ke dalam kartu diskripsi yang disebut kartu fisis. Ada kartu deskripsi versi manual dan ada kartu deskripsi versi aplikasi. Kartu deskripsi versi manual ditulis secara manual, sedangkan versi aplikasi kartu deskripsi ini dicetak langsung dari aplikasi. Untuk saat ini sudah digunakan versi aplikasi karena menghemat tenaga dan waktu.

4. Pembungkusan: setelah arsip dilengkapi kartu deskripsi, maka tahap selanjutnya dibungkus dengan kertas pembungkus, bisa menggunakan kertas payung dan bisa menggunakan kertas casing.

5. Pengentrian data ke Daftar Arsip Inaktif: Tahap ini dilakukan untuk mengisi Daftar Arsip Inaktif. Isi informasi dalam daftar arsip inaktif diambil dari isian di kartu deskripsi.

6. Manufer data: manufer data adalah kegiatan mengurutkan arsip yang telah di entri ke daftar arsip menjadi urut berdasarkan urutan klasifikasi, tahun penciptaan dan bulan pencitaan arsip.

7. Manufer fisik dan penomoran definitive.:manufer fisik adalah kegiatan mengurutkan fisik arsip setelah dimanufer secara data. Pada kegiatan manufer fisik dilakukan juga penomoran definitive, yaitu penomoran arsip setelah proses manuver data.

8. Pengeboksan: Tahap pengebokan adalah kegiatan menata arsip dalam boks arsip. Arsip yang telah di nomori definitif di tata dalam boks arsip. Dalam satu boks arsip, diisi $80 \%$ dari volume boks untuk menghindari boks terlalu penuh sehingga bisa untuk sirkulasi udara.

9. Labelisasi boks arsip dan penyimpanan dalam rak arsip: tahap akhir dari kegiatan pengolahan arsip inaktif adalah labelisasi boks arsip. Yaitu kegiatan melabeli boks 
arsip dengan label untuk memberikan identitas boks arsip, yang memberi keterangan nomor boks dan nomor berkas. Setelah pelabelan selesai dilanjutkan penyimpanan boks dalam rak arsip.

Upaya Dinas Kearsipan dan Perpustakaan Kabupaten Cilacap dalam mengupayakan proses akuisisi arsip statis.

Akuisisi arsip statis sudah dilaksanakan oleh Dinas Kearsipan dan Perpustakaan Kabupaten Cilacap. Akuisisi arsip dilaksanakan pada instansi yang bubar, di merger dan atau dilikuidasi. Akuisisi dilakukan pada arsip yang bernilai statis dan atau memiliki retensi diatas 10 tahun. Beberapa instansi yang sudah diakuisisi arsip statisnya:

1. Bagian Hukum, Bagian Umum, Bagian Organisasi, Bagian Pemerintahan Setda Kabupaten Cilacap.

2. Disperkimta Kabupaten Cilacap.

3. Dishutbun Kabupaten Cilacap.

4. Dipenda Kabupaten Cilacap.

5. KPSKSA Kabupaten Cilacap.

6. Apotik Cahaya Husada Cilacap.

Pemanfaatan teknologi informasi dalam pengelolaan arsip dan pelayanan arsip di Dinas Kearsipan dan Perpustakaan Kabupaten Cilacap:

1. Dalam Pengelolaan Arsip: penggunaan ASOKA (Aplikasi Surat Online Kabupaten Cilacap) merupakan suatu sistem persuratan yang memanfaatkan teknologi informasi sebagai media pencatatannya. Aplikasi ini dibuat dengan mengikuti panduan yang terdapat pada Peraturan Menteri Pendayagunaan Aparatur Negara dan Refromasi Birokrasi Nomor 6 Tahun 2011. Aplikasi ini sudah diterapkan di tiap OPD di Lingkungan Pemerintah Kabupaten Cilacap, akan tetapi baru sampai pada tahap pengelolaan surat masuk. Kedepan akan dikembangkan dan disempurnakan.

2. Pemanfaatan JIKN dalam rangka mempublikasikan arsip statis.

a. Pelayanan wisata arsip dalam rangka memperkenalkan arsip dan sejarah, khususnya sejarah Kabupaten Cilacap melalui pemutaran film sejarah dan film 4 dimensi disamping memperkenalkan khazanah arsip foto.

b. Pembuatan film pendek tentang sejarah Kabupaten Cilacap yang berjudul "TJILATJAP TEMPO DOELOE" yang diunggah dalam youtube.

c. Penggunaan Aplikasi SISUKMA Kabupaten Cilacap (Sistem Informasi Survey Kepuasan Masyarakat). Aplikasi ini digunakan untuk mengukur tingkat kepuasan masyarakat terhadap layanan yang diberikan oleh instansi pemerintah di Lingkungan Kabupaten Cilacap.

Model pelayanan informasi kepada masyarakat: dalam memberikan pelayanan informasi kepada masyarakat, Dinas Kearsipan dan Perpustakaan Kabupaten Cilacap 
sebagai lembaga kearsipan memberikan pelayanan edukasi kepada masyarakat. Pelayanan yang diberikan berupa pelayanan:

1. Konsultasi kearsipan.

2. Layanan Wisata Arsip.

3. Layanan Penggandaan dokumen arsip.

4. Layanan penataan dan penyimpanan arsip inaktif.

5. Layanan Peminjaman arsip.

Sedangkan model pelayanannya adalah tatap muka atau kunjungan langsung. Namun pada masa pandemi saat sekarang pelayanan tatap muka dibatasi dan dengan protokol kesehatan yang ketat. Selain mengisi buku kunjungan dan buku layanan, syarat peminjam dan pengguna arsip adalah membawa dokumen pribadi.

\section{SIMPULAN}

Penelitian tentang pengelolaan arsip lembaga pemerintahan di Dinas Kearsipan dan Perpustakaan Kabupaten Cilacap diperoleh simpulan:

1. Penyelenggaraan kegiatan kearsipan baik dinamis aktif, inaktif maupun statis di Dinas Kearsipan dan Perpustakaan Kabupaten Cilacap telah mengikuti prosedur yang diatur oleh Peraturan Bupati dan pedoman kearsipan yang telah ditetapkan.

2. Pengelolaan arsip baik dari arsip dinamis aktif dilaksanakan dengan mengikuti siklus hidup arsip yang dimulai sejak penciptaan dan penerimaan, pendistribusian, penggunaan, penyimpanan dan temu kembali, dan pemusnahan.

3. Pengelolaan arsip inaktif dilaksanakan dengan tahapan pemilahan, pemberkasan, pendeskripsian, pembungkusan, peng-entri-an data, manufer data, manufer fisik, pengeboksan, labelisasi boks.

4. Pengelolaan arsip statis dilaksanakan dengan langkah akuisisi arsip pada lembaga yang bubar, di merger atau dilikuidasi. Akuisisi dilakukan pada arsip yang bernilai statis dan atau memiliki retensi diatas 10 tahun.

5. Di dalam implementasi teknologi informasi, Dinas Kearsipan dan Perpustakaan Kabupaten Cilacap menerapkan sistem informasi kearsipan yang dinamai ASOKA. (Aplikasi Surat Online Kabupaten Cilacap). Aplikasi ini dibuat dengan mengikuti panduan yang terdapat pada Peraturan Menteri Pendayagunaan Aparatur Negara dan Refromasi Birokrasi Nomor 6 Tahun 2011. Aplikasi ini sudah diterapkan di tiap di lingkungan Pemerintah Kabupaten Cilacap, akan tetapi baru sampai pada tahap pengelolaan surat masuk. Dimasa depan akan dikembangkan dan disempurnakan.

\section{REFERENSI}

Barthos, Basir. 2009. Manajemen Kearsipan. Jakarta: Bumi Aksara.

Endang Nurjati. 2016. Pengelolaan Arsip Dinamis Menjadi Tanggungjawab SKPD dalam bpadjogja.info/article/news/site/view/ id/206/t/ pengelolaan-arsip, diakses tanggal 08 Juni 2020. 
Fajri, Hamdani \& Syahyuman. 2012. Sistem pengelolaan arsip dinamis aktif di Kantor Perpustakaan, Arsip dan dokumentasi Kabupaten Pesisir Selatan. Diakses tanggal 14 Juni 2020 dari http://ejournal.unp.ac.id/index.php/iipk/article/view/1534/1335.

Hadiwardoyo, Syauki dan Yuniarti. 2007. Sejarah Kearsipan. Jakarta: Universitas Terbuka.

Husni, Pertiwi. 2014. Keefektifan sistem informasi manajemen kearsipan (SEMAR) terhadap penemuan kembali arsip di Kantor Perpustakaan dan Kearsipan Kabupaten Sidoarjo, Jurnal Pendidikan Administrasi Perkantoran JPAP Vol. 2 No. 2 tahun 2017 hlm.1-14.

Indonesia. Undang Undang No 43 tahun 2009 tentang Kearsipan.

J. Moleong, Lexy. 2013. Metode Penelitian Kualitatif. Edisi Revisi. Bandung: PT Remaja Rosdakarya.

Mawarni, Puspita Dwi. 2018. Pengelolaan arsip dinamis aktif di Kantor Perpustakaan dan Arsip Daerah Kabupaten Kendal. Diakses pada tanggal 5 Juni 2020 dari https://ejournal3.undip.ac.id/index.php/jip/article/view/22906.

Nana Syaodih Sukmadinata. 2011. Metode Penelitian Pendidikan. Bandung: PT.

Remaja

Rosdakarya.

Nazir. 1998. Metode Penelitian. Jakarta: Ghalia Indonesia.

Nur'aini. 2018. Pascasarjana Ilmu Perpustakaan dan Informasi Alumni Universitas Islam

Negeri Sunan Kalijaga Yogyakarta. Pengelolaan arsip statis pada Badan Perpustakaan. Arsip dan Dokumentasi Provinsi Sumatera Utara. Diakses pada tanggal $28 \quad$ Januari $\quad 2020 \quad$ dari http://jurnal.uinsu.ac.id/index.php/jipi/article/download/1654/1334.

Rahmadeni, Rico dan Syahyuman. 2012. Pengelolaan arsip dinamis aktif di Kantor cabang Perum Pegadaian Marapalam Padang. Jurnal Ilmu Informasi Perpustakaan dan Kearsipan Vol. 1, No. 1, September 2012. Diakses pada tanggal 30 Januari 2020 dari http://ejournal.unp.ac.id/index.php/iipk/article/view/707.

Ricks, M \& Gow, K. 1988. Information Resources Management. A Records System Approach. 2nd edition. Cincinnati: SouthWestern Publishing.

Rusita, Galuh. 2017. Pengelolaan Arsip Statis Di Kantor Perpustakaan Dan Arsip

Kabupaten Kulon Progo, dalam Jurnal UNY. Diakses pada tanggal 2 Februari 2020 dari http://eprints.uny.ac.id/23602/1/Jurnal\%20Galuh.pdf.

Sedarmayanti. 2003. Tata Kearsipan dengan Memanfaatkan Teknologi Modern. Bandung: Mandar Maju.

Sugiyono. 2006. Metode Penelitian Kuantitatif, Kualitatif dan R\&D. Bandung Alfabeta. Sugiyono. 2008. Memahami Penelitian Kualitatif. Bandung: Alfabeta.

Sugiyono. 2011. Metode Penelitian Kuantitatif, Kualitatif dan R\&D. Bandung: Alfabeta. Sugiyono. 2012. Memahami Penelitian Kualitatif. Bandung: Alfabeta.

Sugiyono. 2013. Metode Penelitian Pendidikan Pendekatan Kuantitatif, Kualitatif dan R\&D. Bandung: Alfabeta.

Sugiyono. 2014. Memahami Penelitian Kualitatif. Bandung: Alfabeta.

Sulistyo-Basuki. 1996. Pengantar Kearsipan. Jakarta: Universitas Terbuka.

Sulistyo-Basuki. .2003. Manajemen Arsip Dinamis. Jakarta: Gramedia.

Sulistyo-Basuki. 2006. Pengantar Ilmu Perpustakaan. Jakarta: Paradigma. 
Undang-Undang Nomor 43 Tahun 2009, “Tentang Kearsipan”, diakses pada tanggal 8 Juni 2020 dari upma.vokasi.ui.ac.id/.../Undang\%20-\%20Undang\%20No.\%2043\% 20 Tahun\%2009.

Wursanto, 1991, Kearsipan 1, Yogyakarta: Kanisius Yogyakarta.

Dinas Kearsipan dan Perpustakaan Kabupaten Cilacap. Dinas Arsip Cilacap juara II terbaik nasional wilayah II. Diakses pada tanggal 2 Februari 2020 dari https://arpus.cilacapkab.go.id/dinas-arsip-cilacap-juara-ii-terbaik-nasionalwilayah-ii/.

Dinas Arpus Jateng. 2019. Penyerahan hadiah lomba Bidang Kearsipan dan Perpustakaan tingkat Provinsi Jawa Tengah tahun 2019. Diakses pada tanggal 15 Januari 2020 dari https://arpusda.jatengprov.go.id/nw/berita/penyerahan-hadiah-lombabidang-kearsipan-dan-perpustakaan-tingkat-provinsi-jawa-tengah-tahun-2019. 